\title{
Animal-based Natural Product
}

National Cancer Institute

\section{Source}

National Cancer Institute. Animal-based Natural Product. NCI Thesaurus. Code C106128.

Any substance or product derived from an animal. 